\title{
The Effect of Blogging on Vocabulary Enhancement and Structural Accuracy in an EFL Context
}

\author{
Ramin Rahmany \\ Islamic Azad University, PO Box: 19585-466, Takestan, Iran \\ Bahador Sadeghi \\ Islamic Azad University, PO Box: 19585-466, Takestan, Iran \\ Sajad Faramarzi \\ Islamic Azad University, PO Box19585-466, Takestan, Iran
}

\begin{abstract}
The present study was aimed to investigate the effect of using weblog in language learning as a tool for vocabulary enhancement and grammatical accuracy of Iranian foreign language learners. Previously, weblog has been used as a tool to improve fluency and facilitate communication. However, in this study, the researchers tried to investigate the use of weblog to measure the level of accuracy in writing skill to see the extent in which blogging improves peer feedback and correction. A group of 25 students were selected for five weeks of instruction. Students were assigned to write five articles with pre-determined topics and post them online to their weblogs. While writing the articles students were introduced to use grammar checking softwares and Applications simultaneously. They were invited to correct each other's mistakes and restate the writings by recommending new words. By using Chi-square and Wilcoxon Signed ranks tests, the number of errors and suggested words were analyzed in detail. The results showed that there is a significant increase in the number of words students recommend to each other. Additionally, the number of grammatical errors has decreased dramatically during the peer feedback. According to the questionnaire which was organized after conducting the experiment, almost all students reacted positively to the amount of learning they have received.
\end{abstract}

Index Terms —weblog, blogging, blogger, grammatical accuracy, vocabulary enhancement

\section{INTRODUCTION}

For many years, weblogs or simply blogs have been considered as an online free space for computer users to implement in different fields. For language learning, all four language skills (writing, speaking, listening and reading) can be used by implementing the weblog. Beside these features, it is place for pronunciation check via uploading different softwares which can be used online and a place for vocabulary building (Du \& Wagner 2005). By using weblogs, students can also share a posted topic, not just with a teacher, another classmate, or the whole class, but also possibly with any eager reader online.

The use of weblog as an effective way to teach different skills and alleviating learning problems has been a focal point in teaching foreign languages in recent years. By using weblogs in and outside the classroom the students have the opportunity to work more on different tasks and to reflect on their own learning. They have the chance to reconsider the chosen words and phrases in more time and in a quite relaxed condition without any stress and anxiety. Furthermore, as it is desired, weblog is a tool for peer correction. It is highly recommended by many scholars to implement as a tool to involve all students in order to correct each other and to provide an active participation by all students (Mynard 2007; Noytim 2010; Dippold 2010).

The appeal of a Weblog lies within the fact that it enhanced by its 'multimodality' which includes texts (profile, reflections, and feedback), colors, images, audio and video files, and hyperlinks of websites of the author's interests (Smith \& Baber; 2005; Du \& Wagner, 2005; Miyazoea and Anderson 2012; Montero-Fleta\& Pérez-Sabater 2010; Pop 2010, Richardson 2008,).

In order to post weblogs, bloggers create their writings and monitor them carefully because they know their works will be published online and the rest of students can view it, therefore, it is very easy to be a target of criticism. After reading the weblogs, readers try to give feedbacks to blog writers by providing same sort of feedback. Therefore, writing weblogs can create a sense of "critical thinking" (Noytim 2010, p.1128). Research on weblog had clearly proved that this instrument has the capacity of elevating learner autonomy. The previous works have mainly dealt with the qualitative study i.e. working on issues such as different attitudes of teachers and students toward implementing the use of weblog. However, little or no research conducted the quantitative study of enumerating the results via statistics. In this study, the researchers tried to measure the amount of learning by particularly focusing on vocabulary 
development and the measure in which blogging can affect the grammatical accuracy i.e. to what extend blogging can reduce the amount of errors and mistakes in writing. These issues have never been experienced before.

\section{LITERATURE REVIEW}

\section{A. Using Weblog to Develop Literacy}

The weblog can be used as a tool for language learning. There have been a lot of examples of using weblogs in reading and writing classes (Akcay \& Arslan 2010; Averianova, 2012; Azizinejad \& Hashemi 2011; Beach et al.2009; Bicen at al. 2010; Gokcearslan \& Seher Ozcanb 2011).

Even though weblogs have a lot of advantages in different areas, it has one disadvantage. The weblog is ordered based on the chronology of the latest and the most recent post. Therefore, another topic or post, even more important than others will downfall to the bottom of the list. Tseng (2008) underscored the probability of passivation during blogging and the potential of "distraction" for students.

Guth and Helm (2011) considered Weblog as influential in developing "multiliteracies" which is one of the different devices of telecommunication. In a shared study they claimed that different online collaborative tasks will lead to different "linguistic", communicative" and "intercultural" skills (p.42).

Weblog is considered as a tool for students and language learners to reflect on their own experience (Mynard 2007). Using weblog for language classrooms provides a situation for "authentic learning environment" (Du \&Wagner 2005, Guth and Helm 2011, Zhang 2009, Pinkman 2005, Sevelj 2006). Tseng (2008) found the usefulness of blogs in English classes for students of medicine as a way to practice "free writing" and "peer correction". (p. 180)

Blogging as a tool for learner autonomy

By writing and posting on a personal weblog, students can really feel a sense of "ownership". (Yang et al 2005, Lowe \& Williams, 2004, Zhang, 2009, Du \& Wagner 2005, Campbell 2003). Therefore, they must be accountable about the content of everything they post on their pages. These pages are accessible to others to see and comment on (Lowe \& Williams, 2004).

\section{B. The Effect of Using Weblog on Different Skills}

Blogging has always been considered as a tool for integrating different skills specifically reading and writing. It was an idea first time mentioned by Zamel (1992) that reading provides "comprehensible input" for writing. It has been mentioned that, "just as reading provides 'comprehensible input' for writing, writing can contribute comprehensible input for reading" (Zamel 1992. p. 480).

Noytim (2010) described weblog as "an opportunity and freedom for self-expression in English, writing for both a global and local audience" (p. 1127). Ferriter (2009) believes that reading and writing weblogs have equal importance in language learning. Montero-Fleta and Perez-Sabater (2010), argued that the use of blogs for language related purposes, will result in improving students' motivation and writing quality.

Mynard (2007) investigated the role of weblog writing on reflection on language learning and learner autonomy.He concluded that this can be a tool to encourage students to reflect on their learning. According to Kavaliauskiene and Mazeikiene (2006), the practice of blogging can improve learner autonomy by "raising awareness" of what they are doing through the activity. Similarly, Nhattacharya and Chauhan (2010) argued that blogging can develop cognitive and metacognitive skills in order to assist making more thoughtful decisions.

In order to highlight the linguistic features and accuracy of blogging experience, Wang (2009) examined the role of "blog-assisted electronic feedback" on the amount of feedback that language learners receive. The research concluded that it is obligatory to train students on how to edit their peer's blog writings and stimulate student to learn the cooperative aspects of this experience. According to Averianova (2012) the use of such devices has been popularized in the recent decades. First of all students feel motivated to use the weblog or other "electronically mediated communication" resources.

Additionally, the use of such devices is without any restriction and learners can use them in order to interact with other participants like their friends or more global audience. (Sevelj 2006). Amir et al. (2011) mentioned blogging as one of the tools in which it facilitates the process of writing research projects. As far as writing a journal is individually laborious and a "painful experience", writing these projects within a group can be outstandingly incredible.

The philosophy of using blogs in writing and vocabulary classes lies behind the fact that it ultimately improves students' level of language. Many studies mentioned the usefulness of blogs in order to maximize the students' collaborative writing. (Du \& Wagner 2005, Amir et al. 2011, Mynard 2007).Using blogs in language classes is a good way to improve and promote the cooperation between peers in different skills. In an experiment, Akcay and Arslan (2010) investigated the role of weblog in improving the writing skills among Turkish educators.

Fellner and Apple (2006) investigated the use of weblogs on enhancing writing fluency and improving lexical complexity of Japanese learners. The researchers reached the conclusion that by the end of the program, students were able to triple the number of lexical words to $350 \%$ increase of words. This increase of words was doubled among lower frequency words. The activities in this experience include, listening, online reading, and word building through blogs. Liou and Peng (2006) investigated the role of weblog on improving the writing abilities of thirteen freshman students. 
In the experiment, they tried to observe the impact of training and instruction on students' writing abilities. At the end of the experiment, students felt more confident about their useful peer feedbacks.

Students' attitudes toward weblog and peer review

Dippold (2010) investigated the amount of feedback students give while using the weblog. It was concluded that both the teacher and students enjoyed and benefitted from utilizing blogging inside the class. Wu (2006) investigated the students' reaction to two different kinds of monitoring in the blogging experience which are peer correction and teacher correction. Wu concluded that blogs can be used as an effective instrument which can "provide a forum for social interaction, learning collaboration, negotiation of meaning." (p. 137). Wu investigated the students' reaction to two different kinds of monitoring in the blogging experience which are peer correction and teacher correction. Wu concluded that blogs can be used as an effective instrument which can "provide a forum for social interaction, learning collaboration, negotiation of meaning." (p. 137).

Trajtemberg and Yiakoumetti (2011) emphasized the role of blogging in elevating students' "interaction". They differentiated the difference between the student-initiated and teacher initiated interactions. It was concluded that in many cases, the student-initiated interaction were more effective in improving students "self-expression" and "selfevaluation" (p.438). Bruffee (1984) asserted that using weblogs can facilitate a cooperative meaning making environment in which it reduces the amount of stress that the students have in such writing classes.

Synchronous and asynchronous use of blogs with other online tools

In an experiment on engineering course, Chen et al. (2005) investigated the implementation of simultaneous use of weblog and wikis which they call as "Folio Thinking". Although the study was not conclusive but they maintained that the findings show that students have changed to be more "aware of their own development" and elevated their writing level.

Duffy and Bruns (2006), discussed the viability of simultaneous use of blogs, wikis and RSS feeds in education. The researchers maintained that the influence of concurrent use of these materials are: "collaborative content making" "formative peer assessment" instead of traditional summative assessment, reflecting on language learning experience collectively, and getting "up-to-date information" (p.3). Similarly in another study, Miyazoe and Anderson (2010) analyzed the students' understanding of utilizing simultaneous asynchronous tools, Forums, Blogs and Wikis. By a triangular study which was a combination of survey, interview and text, students perceived language learning in this way as positive in a mixed style.

\section{RESEARCH QUESTIONS}

Based on our considerations, three questions regarding the usage of weblog were targeted in this research. These are:

1. Does Blogging have any effect on vocabulary enhancement?

2. Does Blogging have any effect on structural accuracy of students?

3. Do students have any special feeling toward vocabulary enhancement and structural accuracy after experiencing the use of the weblog?

\section{MATERIALS AND METHODS}

\section{A. Participant}

In this experiment, initially 40 students have chosen from a foreign language institute in Tehran. The participants, aged between 20 to 35 years old, both male and female, had already passed 15 terms of conversation courses and finished the FCE course successfully. However, in order to be certain about the homogeneity of students, a placement test has been taken from the students too. The test was chosen from online Cambridge proficiency test builder which were consisted of grammar and vocabulary items. 25 students were selected out of 40 in order to do the experience.

Materials

In order to educate and instruct students on how to participate, the following instruments were employed subsequently.

\section{B. Online Vocabulary Enhancement Tools}

In order to motivate students to work on the vocabulary side of the project, the students were asked read the 5 writing about 5 predetermined and pre-planned topics. One of the features of this experience is to measure the effect of synonym and antonym website on students' abilities to rephrase and change their previous structures. Accordingly, a model website e.g. ®Merriam-Webster Online Thesaurus App, was introduced to students to recommend words. It should be noted that students received the instruction of how to use these devices from the beginning of the third writing. The results of the number of words which they could propose for each writing has been counted in detail. In writing weblog posts students have the chance to reflect on the appropriateness of the lexical items that they write together and try to change the words with more academic and more context related words by posting their comments for each post. Another device which can be employed both online and offline is the famous word processor software, Microsoft Word. By using this device, students can replace their selected words.

\section{Online Grammar Checking Websites}


By utilizing two online devices students learned to be more cautious about the kind of product that they are writing and posting to be seen by public. These websites which are online grammar checking softwares can check and correct the mistakes and errors regarding grammatical structure, punctuation and spelling mistakes and errors. By using the websites which were <www.spellcheckplus.com> and <www.reverso.net/spell-checker/english-spelling-grammar>, students will receive awareness about the weak points in their writings.

\section{Procedure}

The selected students were invited to the experiment and they received 5 weeks of instruction and in order to learn the use of weblog to improve their writing and vocabulary skills. In the first stage students should have a clear insight of how to blog and what to blog. In this experiment they were required to make a weblog page by using the free and userfriendly blog provider, blogfa. After registration, students exchanged their weblog addresses or simply their URLs with their teacher and the rest of the participants in the experiment via email and text messaging. An important part of the experience is raising students' awareness on what to write. In order to compare students' writing and vocabulary levels, the participants were required to write about five distinct topics which were the same for all the members. The topics for 5 writings included: writing about their jobs, their families, their education, their hometowns and their free times.

After finishing the writings, the results of counting the frequency of comments posted online, the number of mistakes and errors, the number of relevant recommended words should be analyzed in detail. Students were encouraged to correct the posted writings. In order to realize students' attitudes and feelings toward the experience, a questionnaire has been distributed among the students. They were required to answer the 17 questions in the questionnaire which discovered their feelings and attitudes toward different elements of the experience.

\section{E. Data Analysis}

In this research, students were treated to use different devices for vocabulary enhancement at the beginning of writing 3 and grammar checking devices from the start of the second writing. Therefore the analysis of the Chi-Square was used to analyze the vocabulary improvement. Because thirteen different Non-parametric errors were selected to be discussed among 25 students in 5 different writings, NPar Tests were used to measure the discrepancy between paired elements.

\section{RESUlTS AND DisCUSSIONS}

\section{A. The Effect of Blogging on Vocabulary Enhancement}

An analysis of Chi-square is run to compare the number of vocabulary related comments in the first, third and fifth topics. As displayed in Table 1, the students have made vocabulary related comments in the first (residual = -6.7) and third (Residual $=-3.7$ ) topics less than what was expected while they made vocabulary related comments in the fifth topic more than what was expected (residual $=10.3$ ).

TABLE 1:

FREQUENCIES, EXPECTED AND RESIDUALS

\begin{tabular}{|l|l|l|l|}
\hline \multicolumn{5}{|l}{ FREQUENCIES, EXPECTED AND RESIDUALS } \\
\hline Topic 1 & Observed N & Expected N & Residual \\
\hline Topic 3 & 10 & 16.7 & -6.7 \\
\hline Topic 5 & 13 & 16.7 & -3.7 \\
\hline Total & 27 & 16.7 & 10.3 \\
\hline
\end{tabular}

The results of the analysis of chi-square $(\mathrm{x}(2)=9.88, \mathrm{P}=.007<.07)$ indicate that the differences observed in Table 1 are statistically significant. Thus the first null-hypothesis as Blogging does not have any effect on vocabulary enhancement is rejected. The blogging has enhanced vocabulary learning significantly.

TABLE 2:

CHI-SQUARE ANALYSIS

\begin{tabular}{|l|l|}
\hline \multicolumn{2}{|l|}{ CHI-SQUARE ANALYSIS } \\
\hline Chi-Square & Vocrelated \\
\hline df & $9.880^{\mathrm{a}}$ \\
\hline Asymp. Sig. & 2 \\
\hline a. 0 cells $(0.0 \%)$ have expected frequencies less than 5. The minimum expected cell frequency is 16.7. \\
\hline
\end{tabular}




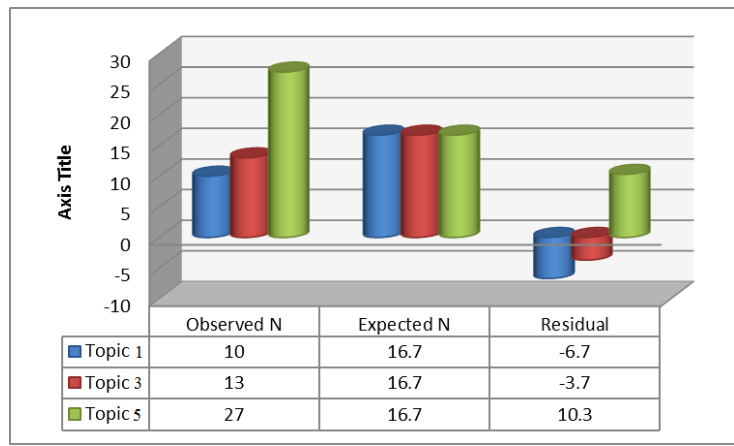

Figure 1: Frequencies, Percentages and Residuals of recommended words

\section{B. The Effect of Blogging on Grammatical Accuracy}

In order to analyze any kind of difference in students' mistakes and errors, the researchers tried to enumerate the number of all errors which participants made and categorized them into 13 different categories. These error types included Subject/verb disagreement, incorrect part of speech, problems with tenses, word order, punctuation errors, Capitalization errors, incorrect use of infinitive, incorrect use of preposition, incomplete sentence, possessives, using wrong articles, using wrong pronouns, incorrect use of auxiliary verbs. Because thirteen different Non-parametric errors were selected to be discussed among 25 students in 5 different writings, NPar Tests were used to measure the discrepancy between paired elements. In this experiment, Wilcoxon Signed Ranks Test was used which is used to compare two dependent abnormal populations.

This test was done to determine the significant difference between each two variables. If the test resulted with $95 \%$ confidence from Asymp. Sig. (2-tailed) then, the result of the test should be compared with the $0.05 \%$ of error. If the amount of Asymp. Sig. (2-tailed) is lower than 0.05, then the assumption of equality between two variables will be nullified. Otherwise, there is no reason to reject the assumption of having $0.05 \%$ error difference. By rejecting the premise of 0.05 percent of error, if the amount of $\mathrm{Z}$ is negative, then the negative detraction of each pair e.g. "capitalization2 - capitalization1" is lower than the positive detraction of that particular pair.

Because the result of Asymp. Sig. (2-tailed) is lower than $0.05 \%$ the assumption of zero difference is obviated and the highlighted pairs in table 3 have significant difference. It is concluded that with $95 \%$ confidence, the amount of capitalization errors in topic 1 were more than topics 3, 4, and 5 because the amount of $\mathrm{Z}$ is negative for topics 3 , 4, and 5. On the other hand, the amount of Asymp. Sig. (2-tailed) of the comparison between capitalization 2-capitalization 1 is more than 0.05 . Accordingly there is no difference between fluctuating the amount of capitalization errors in topic 2 comparing to topic 1 . It is concluded that the use of grammar checking devices significantly decrease the amount of capitalization errors among students

TABLE 3:

WILCOXON TEST FOR CAPITALIZATION ERROR PAIRS

\begin{tabular}{|c|c|c|c|}
\hline \multicolumn{3}{|l|}{ Test Statistics $^{\mathrm{c}}$} & \multirow[t]{2}{*}{ Test Results } \\
\hline & $Z$ & Asymp. Sig. (2-tailed) & \\
\hline capitalization2 - capitalization1 & $-1.890^{\mathrm{a}}$ & .059 & Significant With $95 \%$ confidence \\
\hline capitalization3 - capitalization1 & $-2.236^{\mathrm{a}}$ & .025 & Significant With $95 \%$ confidence \\
\hline capitalization4 - capitalization1 & $-2.236^{\mathrm{a}}$ & .025 & Significant With $95 \%$ confidence \\
\hline capitalization5 - capitalization1 & $-2.236^{\mathrm{a}}$ & .025 & Significant With $95 \%$ confidence \\
\hline \multicolumn{3}{|c|}{$\begin{array}{l}\text { a. Based on positive ranks. } \\
\text { b. The sum of negative ranks equals the sum of positive ranks. } \\
\text { c. Wilcoxon Signed Ranks Test }\end{array}$} & \\
\hline
\end{tabular}

It is concluded that the use of grammar checking devices significantly decrease the amount of capitalization errors among students. According to table 4, by analyzing the result of the test, there is no significant change between these pairs because the amount of Asymp. Sig. (2-tailed) is more than $0.05 \%$. It means that students were not able to correct erroneous structures related to incomplete sentence structure. 
TABLE 4:

WILCOXON TEST FOR INCOMPLETE SENTENCE STRUCTURE ERROR PAIRS

\begin{tabular}{|l|l|l|l|}
\hline Test Statistics & \multicolumn{2}{l|}{ Test Results } \\
\hline incomplete sentence2 - incomplete sentence1 & Z & Asymp. Sig. (2-tailed) & \\
\hline incomplete sentence3 - incomplete sentence1 & $-1.000^{\mathrm{a}}$ & .317 & Not Significant with 95\% confidence \\
\hline incomplete sentence4 - incomplete sentence1 & $-1.000^{\mathrm{a}}$ & .317 & Not Significant with 95\% confidence \\
\hline incomplete sentence5 - incomplete sentence1 & $-1.000^{\mathrm{a}}$ & .317 & Not Significant with 95\% confidence \\
\hline incomplete sentence3 - incomplete sentence2 & $-1.134^{\mathrm{a}}$ & .257 & Not Significant with 95\% confidence \\
\hline incomplete sentence4 - incomplete sentence2 & $-.577^{\mathrm{a}}$ & .564 & Not Significant with 95\% confidence \\
\hline incomplete sentence5 - incomplete sentence2 & $-.577^{\mathrm{a}}$ & Not Significant with 95\% confidence \\
\hline incomplete sentence4 - incomplete sentence3 & $-1.000^{\mathrm{a}}$ & Not Significant with 95\% confidence \\
\hline $\begin{array}{l}\text { incomplete sentence5 - incomplete sentence3 } \\
\text { incomplete sentence5 - incomplete sentence4 }\end{array}$ & $-.000^{\mathrm{b}}$ & 1.000 & Not Significant with 95\% confidence \\
\hline $\begin{array}{l}\text { a. Based on positive ranks. } \\
\text { b. The sum of negative ranks equals the sum of positive ranks. } \\
\text { c. Wilcoxon Signed Ranks Test }\end{array}$ & $-1.000^{\mathrm{a}}$ & .317 & \\
\hline
\end{tabular}

The degree of decline in errors were mostly related to Capitalization, Incorrect auxiliary verbs, Incorrect part of speech, Incorrect use of prepositions, Punctuation, Subject/verb disagreement, Tenses, and Wrong article. However, there were no observed meaningful and significant differences in decreasing the incomplete sentence, incorrect use of infinitive, Possessive, Word order, Wrong pronouns errors.

Blogging has enhanced grammatical accuracy significantly by reducing the amount of errors students make, in other words, the amount of observed errors after treating the grammar checking devices through blogging in the experiment decreased dramatically.

\section{Students' Attitudes toward Blogging}

The third research question investigates the students' reaction and attitude toward their vocabulary enhancement and the level of obtained structural accuracy after finishing the experiment. The null hypothesis states that students do not have any specific feeling toward the experiment. In order to enquire about students' feelings, a questionnaire containing 17 questions on 5 scale answer has been distributed among students. Interestingly students had positive opinions about the experiment as it was expected. Therefore, the third null hypothesis stating that students have no special feeling toward the blogging experiment is rejected. According to the questionnaire results, about $70 \%$ of students enjoyed being evaluated by other peers. However, nearly half of the students still believe that writing a good blog post is time consuming. Interestingly, more than $60 \%$ of the students felt confident to use weblog as a tool to express themselves freely. Students' attitudes toward their improvement in writing have changed. About $70 \%$ of students believed that blogging have improved their writing abilities shown in figure 2 .

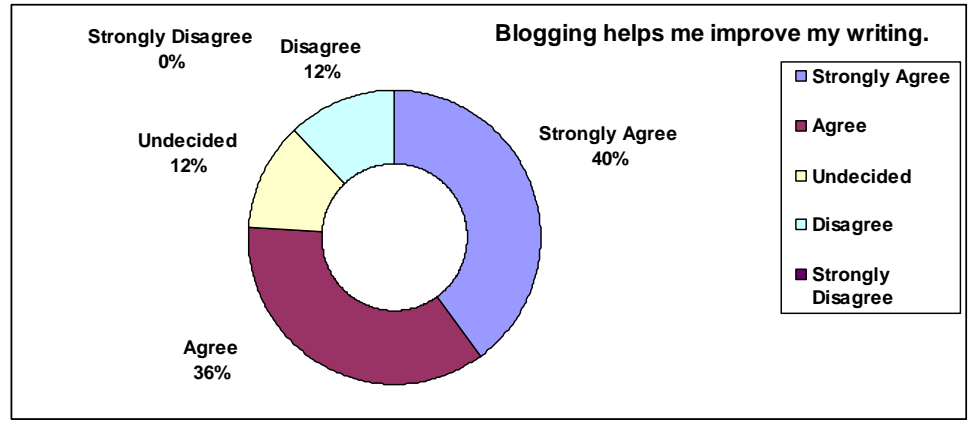

Figure 2: Blogging effect on writing improvement

Almost all of the students believed that blogging changed their attitudes toward language learning and writing in English as it is shown in figure 3. It is a major improvement that by introducing blogging to the educational system, a possible change in students' attitude is expected. 


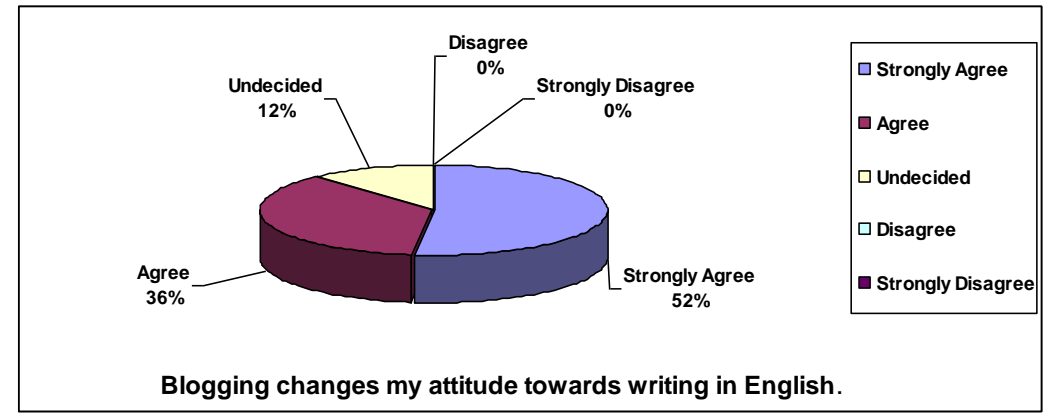

Figure 3: Blogging effect on changing students' attitude

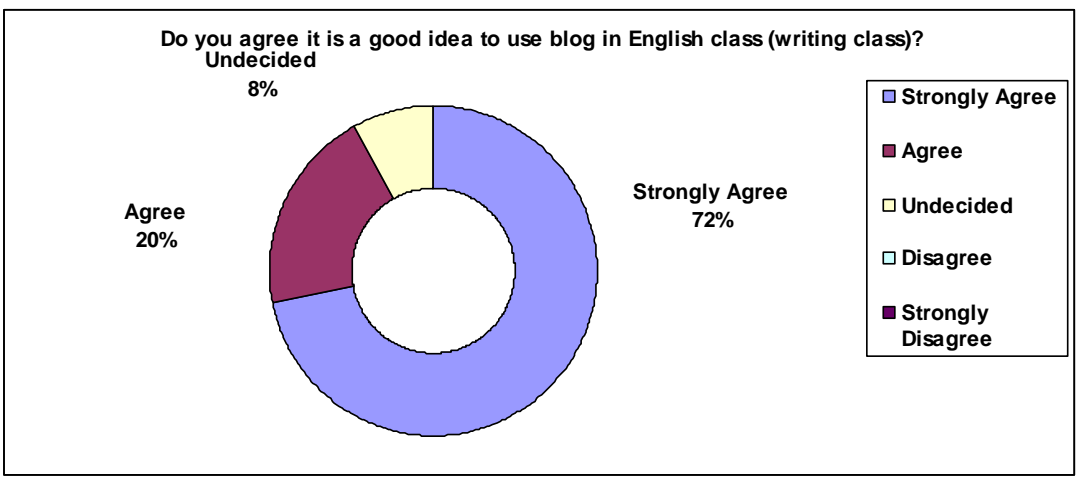

Figure 4: Blogging effect to be included in the curriculum

Almost all students were unanimous to claim that weblog is a useful tool to be implemented inside classroom in order to boost writing abilities. As it is shown in Figure 18, students believe that weblog should be included in writing as part of the main program.

As it is clearly visible in figures 5 and 6 , more than $70 \%$ of students believed that this experience noticeably changed their writing abilities by creating more complicated structures and learning new words.

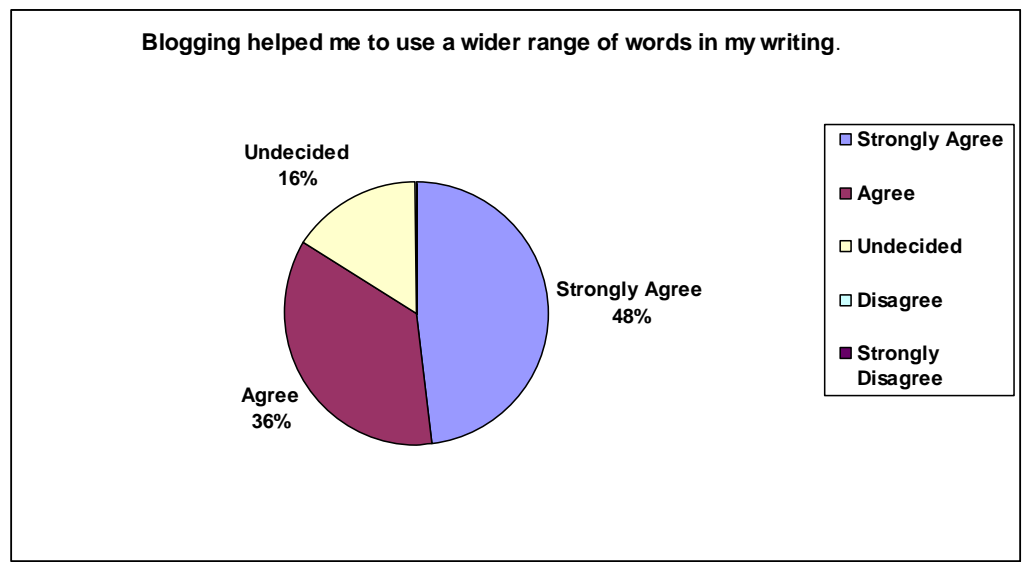

Figure 5: Blogging effect to use a wider range of words

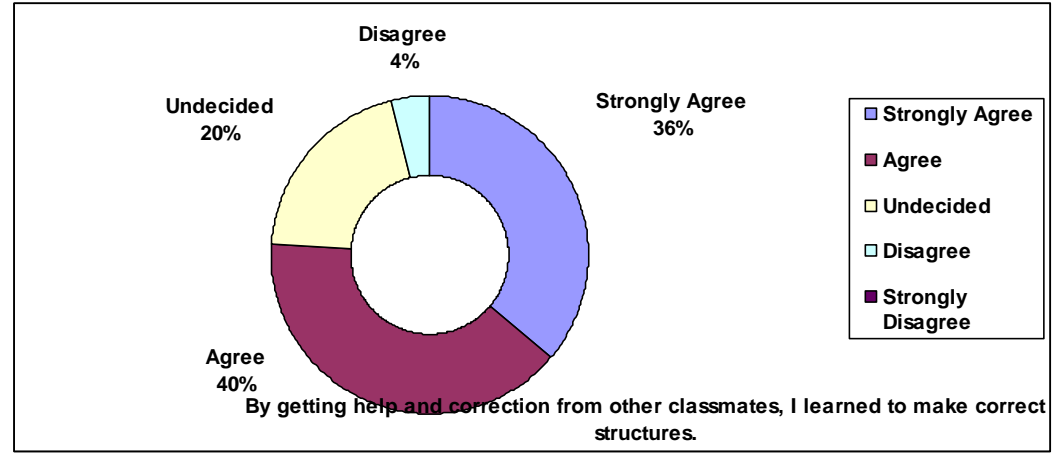

Figure 6: Blogging effect on using correct structures 


\section{CONCLUSIONS}

The results of the experience clearly demonstrate that by counting the number of words for each topic, students recommended more words for each other from topic 3 to topic 5. The reason is quite clear. At the end of the second writing, students were introduced to use grammar checking devices and thesauruses i.e. there is an upward trend for the number of comments related to vocabulary. Interestingly, students used the Merriam-Webster App for vocabulary enhancement effectively along the experience. Students feel it like a competition to recommend new words more comparing to others. This study investigated the amount of error correction in 5 different stages. The results indicated that by checking their writings in grammar checking websites students became more aware of their own writings.

Before posting any topic online students tried to check their work many times in order to post something that clearly demonstrated their utmost abilities. However, other students tried to continually criticize the errors and mistakes. The amount of criticism and comments related to grammar shows that students became more confident and cautious. The decrease in the number of 13 error categories clearly shows that students tried to avoid making errors for the next time they tried to post another topic online. Students acquired an ability to avoid repeating the previous errors.

The result of this research is in agreement with the previous statements that considered weblog as a tool to encourage and facilitate the exchange of resources and thoughts, and enable students' work to be evaluated and assessed by peers (Williams \& Jacobs, 2004). Similarly the result of this research clearly shows that students felt confident and excited to post their writings online which is viewed and judged by others.

In previous researches (Pinkman 2005, Du \& Wagner, 2005, Noytim 2010) the effect of feedback and color variation were accentuated. Similarly in this research, most of the students believed that different choices within the blogging experience e.g. more graphic options for pictures, color, font size, and different styles, audio and video files made English language learning more interesting.

Guth and Helm (2011) considered Weblog as influential in developing "multiliteracies" which is one of the different devices of telecommunication. Similarly in this research project, students found weblog as a tool to go beyond classroom hurdles.

Blogging is considered as a tool for students and language learners to reflect on their own experience. (Mynard 2007). In this experiment, students became aware of their own potentials by checking their writings in other software devices and by getting feedback from other peers.

Blogging is considered as a tool for students and language learners to reflect on their own experience. (Mynard 2007). Similarly in this research, learners discussed their feelings about getting more experience and understanding to write more accurately and with more complicated structures.

Furthermore, in this experiment, students were interested in using blogs as a tool to share ideas with others. Ferriter (2009) emphasized the collaborative aspect of blog writing as the significant aspect of teaching and learning process. In this study, students acknowledged to be more competitive in grammar and vocabulary skills when they share their writings with others.

Pop (2010) also maintains that the concurrent use of different web based materials like weblog will result in "enhancing the students' level of satisfaction, the level of motivation, confidence and disposition" (p. 1185). In this research, Most of the students agreed on the fact that by getting feedback from the other participants in the experiments, they have learned to correct their errors and mistakes themselves.

Noytim (2010) mentioned that the results the study which evaluated by interview and the surveys showed that the majority of the students were in favor of using blogs as it is a tool for building social communication between readers and writers. The major result of this study revealed that weblog is a tool which can develop different strategies of learning like critical thinking.

The result of this experiment is in absolute harmony with that of Montero-Fleta and Perez-Sabater (2010), who argued that the use of blogs for language related purposes will result in improving students' motivation and writing quality. This research emphasized the amount of thinking that each learner would use in order to reflect on their own learning.

Amir et al. (2011) mentioned blogging as one of the tools in which it facilitates the process of writing research projects. Similarly, in this study, by editing and checking the writings in different devices like Microsoft word and grammar checking devices online, students had many options to self-correct themselves or to check others' writings.

The current research proposes the following implications

1. Weblog is a great tool which has to be included in higher education and language learning syllabuses for language learning and other fields of study.

2. It is evident that without the proper education and instruction, students remained to be confused about the goals of the instruction by using weblog. Therefore, organizing classes before the experience is necessary. During workshop classes, students will be familiar with different facilities of devices like weblog.

3. The use of online electronic resources should be encouraged as it was clearly seen that three grammar checking instrument and one vocabulary enhancement software could result in outstanding findings with blogging medium.

4. Students feel more confident and relaxed with electronic and online devices and it is a time saving device to make writing exercises creative. 
5. This research clearly showed that weblog writing is a robust way of leading classes to be more student-centered and interactive.

6. Although, blogging seems to be a bit time-consuming at the beginning, but students will find it user-friendly later on.

7. Blogging is a great tool for assigning different tasks for collaborative learning environment.

8. Blogging can be used in e-learning classes as well. The interactive nature of blogging helps students and teachers to be actively engaged with learning.

9. It is a great tool to enhance accuracy for different skills especially reading and writing.

\section{ACKNOWLEDGMENT}

In the process of writing and managing the practical side of the research, Mr. Arash Norouzi who proved to be a great friend to organize and motivate the students for the project of weblog writing. I would like to express my gratitude to Miss Elnaz Torkameh and Mr. Seyyed Muhammed Hosseini, the manager of KeyhanNo Institute of Foreign Languages. In this research, my students were really helpful and supportive and it is really hard to name all of them.

\section{REFERENCES}

[1] Akcay, A., Arslan, A. (2010). The using of blogs in Turkish education. Procedia Social and Behavioral Sciences 2, $1195-1199$. Retrieved from: www.sciencedirect.com (Jan. 2012).

[2] Amir, Z., Ismail, K., Hussin, S. (2011). Blogs in Language Learning: Maximizing Students' Collaborative Writing. Procedia Social and Behavioral Sciences 18, 537-543. Retrieved from: www.sciencedirect.com (Jan. 2012).

[3] Azizinezhad, M., Hashemi, M. (2011). The use of blogs in teaching and learning translation. Procedia Social and Behavioral Sciences 28, 867 - 871. Retrieved from: www.sciencedirect.com (Jan. 2012).

[4] Averianova, I. (2012). The language of electronic communication and its implications for TEFL. Procedia Social and Behavioral Sciences 34, 14 - 19. Retrieved from: www.sciencedirect.com (Feb. 2012).

[5] Barrios, B. (2003). The Year of the Blog: Weblogs in the Writing Classroom. Computers and Composition Online. Retrieved from: http://www.bgsu.edu/departments/english/cconline/barrios/blogs (March, 2012).

[6] Beach, R., Anson C., Kastman Breuch, L.A., Swiss, T. (2009). Teaching writing using Blogs, wikis and other digital tools. Christopher-Gordon Publishers. Inc. MA: Norwood.

[7] Benson, J., Reyman, J. (2009). Learning to Write Publicly: Promises and Pitfalls of Using Weblogs in the Composition Classroom. Retrieved from: http://www.bgsu.edu/departments/english/cconline/ethics_special_issue/richards/referenes.html (September. 2012).

[8] Bhattacharya, A., Chauhan, K. (2010). Augmenting learner autonomy through blogging. ELT Journal, Oxford University Press. 64/4, 376-384. Retrieved from: http://eltj.oxfordjournals.org (April, 2012).

[9] Bicen, H., Ozdamli, F., Ertac, D., Tavukgu, T., Arap, I. Terali, M. (2010). Education needs of teacher candidates towards web based collaborative learning studies. Procedia Social and Behavioral Sciences 2, 5876-5880. Retrieved from: www.sciencedirect.com (Feb. 2012).

[10] Blanchard, A. (2004). Blogs as Virtual Communities: Identifying a Sense of Community in the Julie/Julia Project. University of North Carolina at Charlotte. Retrieved from: http://blog.lib.umn.edu/blogosphere/blogs_as_virtual_pdf. (Feb. 2010)

[11] Blogfa Electronic Manual reference. (2005). Retrieved from http://www.blogfa.com/Help/ (Aug., 2012).

[12] Campbell, A. (2003). Weblogs for Use with ESL Classes. The Internet TESL Journal. 2(4). Retrieved from: http://www8.ocn.ne.jp/ apc33/ (Feb. 2012).

[13] Chen, H., Cannon, D., Gabrio, J., Leifer, L., Toye, G. (2005) Using wikis and weblogs to support reflective learning in an introductory engineering design course. In: Paper Presented at the Human Behavior in Design '05, Key Centre of Design Computing and Cognition. University of Sydney, Sydney.

[14] Dippold, D. (2010). Peer Feedback Through Blogs: Student and teacher perceptions in an advanced German class. University of Plymouth journal available at: http://eric.ed.gov/ERICDocs/data/ericdocs2/content_storage_01/0000000b/80/2b/c6/bc.pdf. (Dec. 2011)

[15] Du, H. S., Wagner, C. (2005). Learning with Weblogs: An Empirical Investigation. IEEE Transactions on Professional Communication, $50(1)$, $1-9$. Retrieved from: http://infosys3.elfak.ni.ac.rs/Infosys Wiki/attach/SocialCompProject/WeblogLearning.pdf. (Feb.2012)

[16] Duffy, P., Bruns, A. (2006). The Use of Blogs, Wikis and RSS in Education: A Conversation of Possibilities. Proceedings Online Learning and Teaching Conference 2006, pages pp. 31-38, Brisbane. Retrieved from: http://eprints.qut.edu.au.

[17] Enochsson, A. (2011). Who benefits from synchronous online communication? A comparison of face-to-face and synchronous online interviews with children. Procedia - Social and Behavioral Sciences 28, 15 - 22. Retrieved from: www.sciencedirect.com (Feb. 2012).

[18] Fedeli, L., Rossi, P. (2011). A study of teacher/student relations in a formal face-to-face university context supported by online tools within an inactive approach. Procedia - Social and Behavioral Sciences 28, 673 - 678. Retrieved from: www.sciencedirect.com (Feb. 2012).

[19] Fellner, T. (2006). Developing writing fluency and lexical complexity with blogs. The JALT CALL Journal, 2006, Vol. 2, No. 1, pp. 15-26. Retrieved from: http://journal.jaltcall.org/articles/2_1_Fellner.pdf. (Feb. 2012)

[20] Ferriter, B. (2009). Learning with Blogs and Wikis. Educational leadership. 66(5), 34-38.

[21] Godwin-Jones, R. (2003). Emerging Technologies: Blogs and Wikis: Environments for On-line Collaboration. Language Learning \& Technology, 7(2), 12-16. Retrieved from: http://llt.msu.edu/vol7num2/emerging/ (Feb. 2012). 
[22] Guth, S., Helm, F. (2011). Developing multiliteracies in ELT through telecollaboration. ELT Journal, Oxford University Press. 66/1. Retrieved from: http://eltj.oxfordjournals.org (April, 2012).

[23] Kavaliauskienė, G., Anusiene,L., Mazeikiene, V. (2006). Application of Blogging for Learner Development. Journal of Language and Learning .4(2), 133-143. Retrieved from: http://www.jllonline.co.uk/journal/jllearn/4_2/LEARN1.pdf. (March, 2012)

[24] Liou, H., Peng, Z. (2009). Training effects on computer-mediated peer review. System 37,514-525. Retrieved from: www.sciencedirect.com (Feb. 2012).

[25] Lowe, C., Williams, T. (2004). Moving to the Public: Weblogs in the Writing Classroom Weaving a virtual web: Practical approaches to new information technologies. Retrieved from: http://blog.lib.umn.edu/blogosphere/moving_to_the_public.html.

[26] Luik, P., Voltri, O., Taimalu, M., Kalk, K. (2011). On the use of student teacher blogs during teaching practice. Procedia Social and Behavioral Sciences 11, 165-169. Retrieved from: www.sciencedirect.com (Feb. 2012).

[27] Martindale, T., Wiley, D.A. (2005). Using weblogs in scholarships and Teaching. ProQuest Education Journals. 49(2), 55-61. Retrieved from: http://web.thu.edu.tw/chen802/www/out.pdf. (Jan., 2012).

[28] Miyazoe, T, Anderson, T. (2012). Discuss, reflect, and collaborate: A qualitative analysis of forum, blog, and wiki use in an EFL blended learning course. System 38,185e199. Retrieved from: www.sciencedirect.com (Feb. 2012).

[29] Miyazoe, T., Anderson, T. (2010). Learning outcomes and students' perceptions of online writing: Simultaneous implementation of a forum, blog, and wiki in an EFL blended learning setting. System 38 (2010) 185e199. Retrieved from: www.sciencedirect.com (Feb. 2012).

[30] Montero-Fleta, B., Pérez-Sabater, C. (2010). A research on blogging as a platform to enhance language skills. Procedia Social and Behavioral Sciences 2, 773-777. Retrieved from: www.sciencedirect.com (Feb. 2012).

[31] Mortensen, T., Walker, J. (2002) Blogging thoughts: personal publication as an online research tool. In Researching ICTs in Context P.249. Retrieved http://citeseerx.ist.psu.edu/viewdoc/download?doi=10.1.1.156.7392\&rep=rep1\&type=pdf\#page=257. (Feb., 2012)

[32] Murray, H.G., Hourigan, T., (2008). Blogs for specific purposes: expressivist or sociocognitivist approach? Re CALL 20 (1), 82e97. Retrieved from: http://www.aelfe.org/documents/14-02_murray.pdf. (Feb, 2012)

[33] Mynard, J. (2007). A blog as a Tool for Reflection for English Language Learners. Asian EFL Journal.vol,131-40.Retrieved from: http://philippine-esl-journal.com/August-2008-Vol1.pdf (Feb., 2012).

[34] Nardi, B., Schiano, D.J., Gumberecht, M., Swartz, L. (2010). "I'm Blogging This" A Closer Look at Why People Blog. Retrieved from: https://wiki.cc.gatech.edu/scqualifier/images/9/9b/Nardi-Blogging_as_social_activity.pdf.

[35] Noytim, U. (2010). Weblogs enhancing EFL students' English language learning. Procedia Social and Behavioral Sciences 2, 1127-1132. Retrieved from: www.sciencedirect.com (Feb. 2012).

[36] Pinkman, K. (2005). Using Weblogs in the Foreign Language Classroom: Encouraging Learner Independence. The JALT CALL Journal, 1(1): 12- 24. Retrieved 20 October 2009, from: http://www.jaltcall.org/journal/articles/1_1_Pinkman.pdf.

[37] Pop, A. (2010). The impact of the new technologies in foreign language instruction our experience. Procedia Social and Behavioral Sciences 2, 1185-1189. Retrieved from: www.sciencedirect.com (Feb. 2012).

[38] Richards, J.C., Rodgers (2002). Longman Dictionary of Language teaching and Applied Linguistics. Longman Publication.

[39] Richardson, W. (2008). BLOGS, WIKIS, PODCASTS, and Other Powerful Web Tools for Classrooms. Hawker Brownlow Education CO2437.

[40] Saddington, J. (2010). What is a Blog? What is a Blogger? What is Blogging?. Electronic journal. Retrieved September 23. 2012 from http://tentblogger.com/blog-blogger-blogging/.

[41] Seitzinger, J. (2006). Be Constructive: Blogs, Podcasts, and Wikis as Constructivist Learning Tools. E-magazine, Practical $\begin{array}{lllll}\text { Applications of for } & \text { Technology }\end{array}$ http://69.18.156.82/21/blogs\%20wikis\%20podcasts\%20learning\%20tools.pdf. (Jan. 2012)

[42] Sevelj, M. (2006). Weblogs as Dynamic Learning Spaces. Retrieved 10 September 2009, from http://grail.oise.utoronto.ca/blog/karaisko/files/2007/12/weblogs_dynamic_learning_spaces.pdf.

[43] Smith, D., Baber, E. (2005). Teaching English with Information Technology. Modern English Publishing. UK: London.

[44] Trajtemberg, C., Yiakoumetti, A. (2011). Weblogs: a tool for EFL interaction, expression, and self-evaluation. ELT Journal Oxford University Press Volume 65/4, 437-445. Retrieved from: http://eltj.oxfordjournals.org (April, 2012).

[45] Tseng, M. (2008). The Use of Blogs in English Classes for Medicine-Related Majors. Chang Gung Journal of Humanities and Social Sciences, 1(1): 167-187. Retrieved from http://memo.cgu.edu.tw/cgjhsc/1-1\%2007.pdf.

[46] Wang, H.-C., (2009) Weblog-mediated peer editing and some pedagogical recommendations: a case study. The JALT CALL Journal 5 (2), 29e44. Retrieved from: http://journal.jaltcall.org/articles/5_2_Wang.pdf. (Feb. 2012)

[47] Wu, W. (2005). Using blogs in an EFL writing class. Meeting of the 2005 Conference and Workshop. Retrieved from: http://web.chu.edu.tw/ wswu/publications/papers/book_chapters/01.pdf. (Feb., 2012)

[48] Wu, W. (2006). The effect of blog peer review and teacher feedback on the revisions of EFL writers. Journal of Education and Foreign Languages and Literature 3,125-139. Retrieved http://people.chu.edu.tw/ wswu/publications/papers/journals/04.pdf. (April, 2012)

[49] Xie, Y., Sharma, P. (2010). Student Experiences Of Using Weblogs: An Exploratory Study. Journal of Asynchronous Learning Networks, Volume 12: Issue 3-4. Retrieved from: http://g2bloggersarticles.yolasite.com/resources/Graduate\%20Blogs.pdf. (March. 2012)

[50] Yang, A., Chan, A., Lik-ko Ho, L., Tam, B, (2005). Does an open forum promote learning among students? A collaborative learning approach. Asian EFL Journal, 7(3). Retrieved from: http://asian-efl-journal.com/sept_05_ay.pdf (June 2008).

[51] Zamel, V. (1983a). The composing processes of advanced ESL students: Six cases studies. TESOL Quarterly, 17, 165-187. Retrieved from: http://tesol.aua.am/TQD_2000/TQD_2000/TQ_D2000/VOL_26_3.PDF\#page=40. (Feb., 2012)

[52] Zhang, D. (2009). The Application of Blog in English Writing. Journal of Cambridge Studies, 4(1). Retrieved 20 October 2009. Retrieved from: http://journal.acs-cam.org.uk/data/archive/2009/200901-article8.pdf (Jan. 2012). 


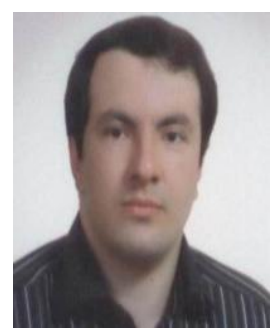

Ramin Rahmany is a Ph.D. holder of teaching English as a foreign language from Tehran University, Iran. Currently, he is an assistant professor in Azad University of Takestan, Iran.

His major interests are language and acquisition, computer assisted language learning, and psycholinguistics. He has taught several courses at university like Language methodology and discourse analysis.

He has published several articles in language learning acquisitions e.g. Acquisition of English Relative Clauses by Persian EFL Learners published by Journal of Language and Linguistic Studies in October 2009.

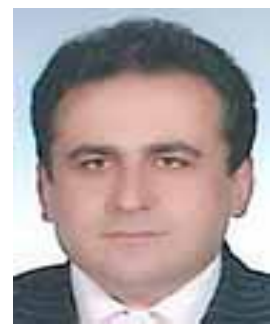

Bahador Sadeghi, an assistant professor of Applied Linguistics holds a doctorate degree in TEFL from the University of Isfahan, Iran. He also holds three MAs in TEFL, English Translation and International Relations from Tehran Islamic Azad University, Isfahan University and Allameh Tabatabaee University respectively.

He has been lecturing different subjects in TEFL, Translation studies, General English and ESP at several universities in Iran for the last nineteen years. He has both published and presented a number of articles in some international journals and conferences.

Dr. Sadeghi is the co-author of a book (with Hossein Vahid Dastjerdi, PhD) entitled "An Anthology of Translated Religious \& Literary Texts (With a Glossary of Islamic Terms)" and has translated eight other books from English to Persian.

Dr Sadeghi is also a certified translator to the judiciary power in Iran and he has been, as a simultaneous interpreter, actively involved in many national and international seminars, sport events and tourism projects.

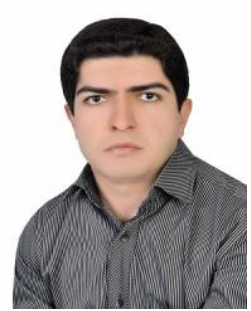

Sajad Faramarzi is an M.A. holder of teaching English as a foreign language from Azad University of Takestan, Iran in 2013. He has his B.A. in English literature from Razi University of Kermanshah, Iran in 2007.

He has been working as a teacher, teacher trainer and an educational manager for 10 years in different language institutions in Tehran. Currently, he is the educational manager and IELTS trainer in Iranmehr Technical Language Institute. He has also worked as an interpreter at Razi University of Kermanshah. His major interests are Language Acquisition, Language Testing and Computer assisted Language Learning. 